\title{
Mirada y poder. Una interpretación post-estructuralista del mito de Perseo
}

\author{
Gaze and power. A post-structuralist \\ interpretation on Perseus' myth
}

\author{
Olaya Fernández GuerRero \\ Universidad Nacional de Educación a Distancia \\ olayafg@yahoo.es
}

Recibido: 02/09/2014

Aceptado: 08/12/2014

\section{Resumen}

La mirada jerarquiza, organiza y etiqueta la realidad. Entonces, siguiendo a Foucault, la mirada puede interpretarse como una práctica de poder. Este trabajo se inspira en sus teorías y las aplica a uno de los ámbitos simbólicos más poderosos de la cultura occidental: los mitos griegos. Las nociones de visibilidad, invisibilidad y panoptismo arrojan nueva luz sobre la historia de Perseo y Medusa, y propician una relectura de este mito centrada en las distintas formas de poder que emergen de la mirada.

Palabras clave: Foucault, Gobernabilidad, Mitología griega, Post-estructuralismo.

\begin{abstract}
Gaze hierarchizes, manages and labels reality. Then, according to Foucault, gaze can be understood as a practice of power. This paper is inspired by his theories, and it applies them to one of the most powerful symbolic spheres of Western culture: Greek Myths. Notions such as visibility, invisibility and panopticism bring new light into the story of Perseus and Medusa, and they enable a re-reading of this Myth focused on the different ways of power that emerge from the gaze.

Keywords: Foucault, Governance, Greek Mythology, Post-Structuralism
\end{abstract}



Sumario
1. Introducción: los mitos griegos en la era de los mass media.
2. El mito de Perseo.
3. Panoptismo: el poder de verlo todo.
4. Invisibilidad: el poder de actuar sin ser visto.
5. El ojo como órgano de poder: las Grayas.
6. La mirada de la muerte: Medusa.
7. El avistamiento del premio: Andrómeda.
8. El escudo/espejo: el poder sobre sí.

\section{Introducción: los mitos griegos en la era de los mass media}

Uno de los aspectos que mejor definen la cultura contemporánea es su carácter predominantemente visual. Como ya destacó Sartori, surge en el ser humano actual una nueva dimensión, la de homo videns, que ha modificado profundamente nuestros modos de conocer la realidad e interactuar con ella a todos los niveles. ${ }^{1}$ En la era de la sociedad de la información es evidente la primacía de la mirada sobre todos los demás sentidos, y la consigna de que 'una imagen vale más que mil palabras' se ha convertido en máxima universal. Se constata que el ojo interpreta, evalúa y clasifica lo que aparece ante él mucho más rápido y con mayor intensidad que los demás órganos de la percepción. Los contenidos captados a través de la mirada se integran en sistemas de significado de complejidad creciente, y de esa manera se van articulando regímenes de visibilidad e invisibilidad que remiten directamente a relaciones de poder, como ya señalaron Foucault y Deleuze, entre otros. En los tiempos que corren "los fundamentales instrumentos de producción de subjetividad, los medios de comunicación de masas, son herramienta privilegiada de poder"' ${ }^{2}$ Ser es ser percibido y lo que no se ve no existe. La fórmula es sencilla, pero efectiva, y quienes manejan los hilos del poder lo saben y usan los medios de comunicación para amplificar la visibilidad de ciertos acontecimientos, procesos y discursos, y silenciar otros. Los puntos de vista dominantes se repiten, reproducen y difunden hasta la extenuación a través de múltiples cauces formales e informales, hasta llegar a penetrar en lo más profundo de la psique de los individuos. Es así como el poder produce subjetividades, según el certero análisis de Foucault. En todo ese proceso es fundamental el papel de la mirada, que jerarquiza los objetos captados y les da sentido. El ojo, o bien conceptualiza la realidad siguiendo los paradigmas que ofrecen esos discursos hegemónicos, o bien se resiste a ellos y busca campos visuales alternativos que el discurso oficial y los medios de masas no muestran, para hallar ahí nuevos referentes

\footnotetext{
${ }^{1}$ Giovanni Sartori. Homo videns: la sociedad teledirigida. Madrid: Santillana-Taurus, 1998.

${ }^{2}$ Juan Manuel Aragüés. De la vanguardia al cyborg. Aproximaciones al paradigma posmoderno. Zaragoza: Eclipsados, 2012, p. 276.
} 
desde donde generar miradas críticas, subjetividades antagonistas y prácticas subversivas. Según este esquema, todo acto de mirar puede ser codificado como una práctica de poder.

La 'visibilidad', concepto central en las teorías de los filósofos post-estructuralistas y en Foucault en particular, resulta una herramienta teórica muy útil para explicar diversos fenómenos y procesos de las sociedades contemporáneas. Esa visibilidad guarda asimismo una estrecha relación con el lenguaje, puesto que "el saber es un 'dispositivo' de enunciados y visibilidades" ${ }^{\prime 3}$ que produce la verdad a través del lenguaje y que, mediante ese mecanismo, crea 'etiquetas' y fija las categorías a partir de las que se conceptualiza la realidad. En esa construcción de los saberes el lenguaje opera como una retícula en la que se van insertando diferentes elementos, ajustándose a cada una de las celdas de esa matriz discursiva. Todo lo que no encaja en esa matriz queda fuera, forma parte de lo no verbalizable, de lo inefable, de lo que carece de formato expresivo y que, al no tener cabida en el lenguaje, resulta ininteligible e incognoscible... Ya lo anunciaba Wittgenstein: los límites de mi lenguaje son los límites de mi mundo, y todo lo que cae fuera de mi campo semántico -y de mi campo visual, como pone de relieve Debord cuando teoriza sobre la sociedad del espectáculo- no existe para mí. La mirada y la palabra están interconectadas -Foucault abordó con gran lucidez esta cuestión en Las palabras y las cosas-, hasta el punto de que los regímenes de visibilidad y los regímenes de discursividad confluyen en muchas de las prácticas de poder que realizamos y/o padecemos cotidianamente.

Siguiendo la metodología foucaultiana, el presente estudio se esboza como una 'arqueología del saber' que indaga en las nociones de visibilidad e invisibilidad y en los mecanismos y prácticas de poder asociados a esos conceptos. El itinerario aquí propuesto se retrotrae hasta la mitología griega, uno de los núcleos simbólicos más potentes sobre los que se asienta la filosofía occidental, y de donde emergen elementos apropiados para articular una reflexión crítica sobre la mirada y el poder. Esta temática está presente en muchos relatos míticos y recorrerlos todos trascendería con creces el objetivo de este trabajo, por lo que este análisis se ceñirá a un mito en concreto, el de Perseo, abordado desde la posmodernidad e inspirado en gran medida en las nociones de visibilidad y poder planteadas por Foucault.

El mito resulta interesante porque arrastra consigo un espesor simbólico inagotable; su sentido nunca está dado de una vez por todas sino que en el relato mítico se produce más bien un eterno retorno de lo simbólico, no como una mera repetición de lo idéntico sino como una acumulación entretejida de sentidos, en tanto que las posibilidades expresivas del mito son potencialmente infinitas, tal y como ha puesto de relieve la tradición hermenéutica de la mano de Gadamer y de Oñate, Marzoa o Lledó, en el contexto español. Cada época histórica lleva a cabo una relectura de sus mitos, revistiéndolos de nuevos contenidos y significados, y por ello resulta perti-

\footnotetext{
${ }^{3}$ Gilles Deleuze. Foucault. $2^{\mathrm{a}}$ ed. Paris: Éditions de Minuit, 2004, p. 58.
} 
nente plantear una revisión de los mitos en general, y del relato de Perseo en particular, a través del prisma de la posmodernidad. Porque "la exégesis es el comentario incesante $[\ldots]$ que una cultura se da de su propio simbolismo, de sus prácticas, de todo lo que la constituye como cultura viva", ${ }^{4} \mathrm{y}$ repensar la propia tradición es uno de los mecanismos que hacen que las culturas avancen, se transformen y puedan seguir encontrando nuevas respuestas a las viejas preguntas que la humanidad se ha planteado desde siempre.

La elección de Perseo no es casual, sino que se debe al gran número de referencias que hace este mito a cuestiones relacionadas con la mirada y el poder. A este héroe, hijo de Zeus y Dánae, se le atribuyen entre otras hazañas la de haber decapitado a Medusa, mujer de cabellos serpentinos que petrificaba a todo aquel que posaba sus ojos en ella. La cabeza cercenada conserva intacta esa capacidad de convertir en piedra a quien la mire y Perseo se sirve de ese talismán para derrotar a sus enemigos, aunque acaba donando la cabeza de Medusa a la diosa Atenea, que la coloca en el centro de su escudo. Otros estudios previos ya han apuntado que en este episodio de la mitología "hay un tema que cumple un rol central: es el ojo, la mirada, la reciprocidad de ver y ser visto". ${ }^{5}$ En los siguientes epígrafes se ofrece una interpretación más detallada de los elementos de este mito relacionados con la visibilidad, la invisibilidad y las modalidades de poder asociadas a la mirada.

\section{El mito de Perseo}

De entre todos los mitógrafos clásicos que recogen la historia de Perseo, es el conocido como Pseudo-Apolodoro, o Apolodoro, ${ }^{6}$ el que refiere de forma más extensa los distintos episodios relacionados con este héroe, por lo que este estudio se basará principalmente en su versión. Según la fuente latina, Acrisio, rey de Argos, tuvo una hija, Dánae. Un oráculo había vaticinado al rey que de su hija nacería un hijo, y que este lo mataría. Para evitar que la profecía se cumpliese, Acrisio construyó una cámara subterránea de bronce y encerró en ella a Dánae. Pero Zeus se había encaprichado de la joven y, transformado en lluvia de oro, se filtró a través del techo y cayó sobre ella. De esa unión nació Perseo. Cuando el rey Acrisio supo lo sucedido, puso al niño y a su madre dentro de un arca y los arrojó al mar. El arca llegó hasta la isla de Sérifos, donde el pescador Dictis rescató a Dánae y Perseo y les dio cobijo en su hogar. El hermano de Dictis, Polidectes, rey de Sérifos, se enamoró de Dánae e intentó casarse con ella, pero Dánae lo rechazaba y también Perseo era contrario a

\footnotetext{
${ }^{4}$ Marcel Detienne. La invención de la mitología. Traducción de Marco Aurelio Galmarini. Barcelona: Península, 1985, p. 89.

${ }^{5}$ Jean-Pierre Vernant. La muerte en los ojos. Figuras del Otro en la antigua Grecia. Traducción de Daniel Zadunaisky. Barcelona: Gedisa, 1986, p. 101.

${ }^{6}$ Apolodoro. Biblioteca. Traducción de Margarita Rodríguez. Madrid: Gredos, 1985.
} 
ese enlace. Para librarse del joven, Polidectes le ordenó que le trajese la cabeza de Medusa.

Ayudado por Hermes y Atenea, Perseo llegó hasta los confines del reino de Hades, a un espacio custodiado por las Fórcides: Enío, Penfredo y Dino, también conocidas como Grayas, hijas de Ceto y Forco y hermanas de las Gorgonas. Las Grayas tenían un solo ojo y un solo diente, que compartían. Perseo los cogió y solo accedió a devolverlos cuando las ancianas le hubieran indicado el camino que llevaba hasta las ninfas. Así lo hicieron, y el héroe cumplió su palabra y devolvió el ojo y el diente sustraídos. Las ninfas tenían las sandalias aladas de Hermes, la kibisis -una especie de zurrón- y el casco de Hades, que hacía invisible a quien lo llevase puesto. Con estos artilugios que le proporcionaron las ninfas, y con una hoz de acero que le había dado Hermes, Perseo llegó hasta el lugar donde dormían las Gorgonas: Esteno, Euríale y Medusa. De ellas, solo Medusa era mortal, pero las tres tenían la capacidad de petrificar a quien las miraba. Perseo, guiándose por la imagen de la Gorgona reflejada en su escudo de bronce, la decapitó. Al cortarle la cabeza, surgieron de su cuello el caballo alado Pegaso y Crisaor, un gigante con una espada de oro, a los que había engendrado Medusa con Poseidón, el dios de los mares. Perseo guardó la cabeza de Medusa en el zurrón y emprendió su huida. Las otras dos Gorgonas lo persiguieron para vengar la muerte de su hermana, pero no le dieron alcance porque no lograban verlo, ya que Perseo llevaba puesto el casco de Hades y avanzaba a gran velocidad con las sandalias aladas.

De camino a Sérifos, Perseo salvó a Andrómeda, una princesa etíope ofrecida como sacrificio a un monstruo marino para compensar un agravio de su madre a los dioses. En pleno vuelo, Perseo avista desde el aire a la princesa atada a una roca y atacada por el monstruo; con su espada mata a la bestia y se casa con la princesa, después de vencer, sirviéndose de la cabeza de Medusa, a varios adversarios que se oponían a la boda. Luego, Perseo vuelve a Sérifos a rescatar a su madre, y allí también usa el preciado talismán para petrificar a sus enemigos. Después de dejar Sérifos, el héroe devuelve a los dioses las sandalias, el zurrón y el casco, y entrega a Atenea la cabeza de Medusa, que desde entonces decora el escudo de la diosa.

Perseo, junto a Dánae y Andrómeda, volvió después a Argos y su abuelo el rey Acrisio, temeroso del oráculo, huyó. Poco tiempo después, Perseo estaba tomando parte en una competición deportiva y lanzó un disco que accidentalmente alcanzó la zona donde se sentaba el público. Acrisio, que había acudido a observar la competición sin saber que su nieto estaba allí, fue golpeado por el disco y murió al instante. Perseo vio que se había cumplido la predicción y, para no gobernar en Argos, intercambió ese reino por el de Tirinto, donde vivió muchos años y tuvo una amplia prole junto a su esposa.

La versión del mito de Perseo que ofrece Apolodoro y que aquí se recoge resumidamente, complementada con otros detalles que aparecen en Hesíodo y Ovidio, son las fuentes principales en que se fundamenta este análisis. 


\section{Panoptismo: el poder de verlo todo}

'Panoptismo' significa, literalmente, verlo todo. Este concepto alude a la visibilidad ejercida en grado sumo, implica ocupar una posición de superioridad absoluta con respecto a un campo visual que es controlado y dominado en todos sus detalles.

Foucault afirma que una de las estrategias de poder que mejor caracterizan a las sociedades contemporáneas es la instauración de una jerarquía de la mirada, esto es, el establecimiento de regímenes de visibilidad que se aplican directamente sobre los individuos y que giran en torno a la polaridad de ver y ser visto, pues "el sujeto que ve es él mismo un lugar dentro de la visibilidad, una función derivada de la visibilidad".? La idea del panóptico no es original de Foucault sino que está inspirada en Bentham, filósofo inglés que en el siglo XVIII diseñó un centro penitenciario imaginario que permitiese rentabilizar al máximo la vigilancia. ${ }^{8}$ El panóptico es una prisión circular con una única torre central para el vigía, en torno a la que se distribuyen las celdas de los presos. Desde la torre de vigilancia se divisan todas las celdas, pero desde cada celda solamente puede verse el punto de control central. De este modo, solo hará falta un individuo para vigilar la prisión, y la simple posibilidad de que haya un guarda observando a los presos hace que estos cumplan las normas, por temor a ser descubiertos si las infringen. Este mecanismo de control se basa en la sujeción a un régimen de visibilidad permanente donde lo más disuasorio es el riesgo de ser visto cometiendo una falta, lo que conlleva que el preso respete e interiorice todas las reglas de la prisión.

Estas nociones, inicialmente empleadas para explicar las transformaciones históricas de la gestión de las prisiones, son extrapoladas a otros ámbitos de la sociedad, y Foucault concluye que "quien es sometido a un campo de visibilidad, y lo sabe, interioriza las constricciones del poder". ${ }^{9}$ Estos dispositivos de visibilidad sirven para organizar las colectividades humanas y administrar sus vidas de formas cada vez más eficaces. El panoptismo, resorte de poder basado en el riesgo constante de ser captado in fraganti cometiendo una infracción, garantiza la máxima eficacia de la norma, que se inscribe en la psique de los individuos con total intensidad. Consiguientemente, la ley más poderosa es aquella que no se verbaliza, que no aparece escrita en ningún lugar pero que todos cumplen porque se sienten sujetos a ella, "la presencia de la ley consiste en su disimulación" ${ }^{10}$ y sus mecanismos para modelar las conductas de los individuos son tan potentes como invisibles.

Esta lectura del poder en clave de panoptismo desarrollada por Foucault es susceptible de aplicarse a muchos ámbitos de reflexión; entre ellos, el de la mitología.

\footnotetext{
${ }^{7}$ Deleuze. Op. cit., p. 64.

${ }^{8}$ Bentham mencionó por primera vez sus ideas sobre este tipo de centro penitenciario en unas cartas que escribió en 1787 a su amigo Lord Pelham. Posteriormente, recopiló sus consideraciones sobre la construcción del panóptico en tres volúmenes publicados en Londres en 1791.

${ }^{9}$ Michel Foucault. Surveiller et punir. Naissance de la prison. Paris : Gallimard, 1975, p. 236.

${ }^{10}$ Michel Foucault. La pensée du dehors. $2^{\mathrm{a}}$ ed. Paris : Fata Morgana, 2009, p. 33.
} 
En el panteón griego las dimensiones de visibilidad y legalidad están representadas por la figura de Zeus, que ejerce su autoridad sobre las demás divinidades del Olimpo y asimismo sobre todas las criaturas que pueblan la tierra, los mares y el mundo subterráneo. La mirada de Zeus es panóptica, capaz de llegar a todos los rincones; su conocimiento es omnisciente y nada se le puede ocultar. Lo gobierna todo porque lo ve todo, percibe cada detalle de lo que hacen los humanos y los demás dioses y desde esa posición privilegiada dictamina lo que es bueno o malo, lo que es aceptable o lo que debe ser castigado, desplegando así unas prácticas de legalidad que son, en definitiva, prácticas de poder hegemónico. Zeus despliega su poder instaurando un régimen de visibilidad en cuyo centro se sitúa, y desde donde observa sus dominios "sentado en su trono, flanqueado por el águila que es su símbolo, y empuñando el rayo que es su arma preferida". "Esta divinidad es una sugerente metáfora de la mirada que abarca totalidades, que ve el mundo desde las alturas y que se sirve de los rayos, cuya luz es cegadora, para que todo sea iluminado y nada quede oculto. En síntesis, puede afirmase que la mayoría de los elementos asociados a Zeus aluden simbólicamente a la visibilidad y el poder.

Pero la mitología no presenta a un Zeus modélico y de conducta intachable, sino que en diversos episodios recogidos por los mitógrafos clásicos -Homero, Hesíodo, Ovidio, Apolodoro- afloran debilidades muy humanas e incluso rasgos tiránicos que se ponen de manifiesto cuando este dios se deja llevar por la ira, o cuando utiliza su poder en su propio beneficio y emplea estratagemas muy variadas y creativas para satisfacer sus caprichos. El mito de Perseo es ejemplo de ello, ya que en este pasaje Zeus se encapricha de Dánae y, a pesar de que el rey Acrisio ha encerrado a la joven en una cámara subterránea, consigue con ello ocultarla de las miradas de los humanos pero no de la mirada del Zeus panóptico, que todo lo ve y que además tiene la potestad de actuar sin ser visto. Su ansia por tener un encuentro amoroso le lleva a convertirse en lluvia de oro y filtrarse por las fisuras del techo de la estancia en la que está encerrada Dánae, pasando desapercibido para los guardianes que custodian a la princesa. Zeus consigue así llegar hasta ella y consumar la unión sexual de la que nacerá Perseo, uno de los héroes centrales de la mitología griega.

\section{Invisibilidad: el poder de actuar sin ser visto}

Siguiendo la lectura foucaultiana, someterse al poder implica la sujeción a un régimen de visibilidad en el que los individuos son forzados a actuar siempre bajo la mirada de otro que puede aprobar o censurar sus acciones, esto es, que tiene la capacidad de vigilar y castigar. De ahí se sigue que quien tiene a su alcance la opción de actuar sin ser visto y observar cómo actúan los demás -es decir, quien administra un régimen de visibilidad pero no se somete a él- ocupa una posición jerárquica superior

\footnotetext{
${ }^{11}$ Carlos García Gual. Diccionario de mitos. Barcelona: Planeta, 1997, p. 355.
} 
a la de los individuos que únicamente están a merced de las miradas ajenas. Emerge aquí otra dimensión de poder relacionada con la invisibilidad: la capacidad de actuar ocultamente, también presente en el mito de Perseo; para cumplir con su misión de decapitar a Medusa, el héroe cuenta con la inestimable ayuda del casco de Hades que le prestan las Ninfas y que le permite hacerse invisible, es decir, actuar sin ser visto, con todo el poder que ello le otorga.

Hades es el dios del mundo subterráneo, ese ámbito que resulta un espacio de completa alteridad y opacidad para la mirada humana, pues a los seres mortales les está vedado el acceso a la región de los muertos mientras están vivos y solamente al alma, una vez desprendida de su envoltura carnal, le es permitido contemplar ese reino de sombras -se plasma aquí la cara negativa de la metempsicosis platónica: las almas buenas y sabias regresan al mundo de las Ideas, las almas malas e ignorantes son confinadas a la región de Hades-. Para poder vencer a la Gorgona que habita en el inframundo, Perseo necesita 'disfrazarse' de muerto, es decir, invisibilizar sus rasgos de hombre vivo para poder pasar desapercibido en ese mundo subterráneo al que, en principio, no tiene acceso. Su condición mortal le impide franquear las puertas de la muerte y regresar luego al reino de los vivos; se servirá del casco de Hades para vencer esa dificultad. Dice Hesíodo en su Escudo: "Cubría las sienes del héroe el terrible casco de Hades con la tenebrosa oscuridad de la noche". ${ }^{12}$ La "capucha de piel de perro, que sirve de sombrero al infernal Hades", ${ }^{13}$ oculta y vuelve invisible a quien la lleva, y es este elemento proporcionado por las divinidades el que permite al héroe transitar a su antojo por un territorio prohibido, cumplir con su misión y regresar indemne al espacio terrestre-celeste del que Perseo proviene originariamente. De hecho, recordemos que las sandalias aladas de Hermes, el emisario de Zeus y "señor del límite entre el mundo de los hombres y el inframundo", ${ }_{14}$ forman parte del equipaje de Perseo en esta aventura y le permiten huir más rápido con su botín, la cabeza de Medusa, guardada en una bolsa mágica -la kibisis-, también obsequio de las Ninfas.

El casco hace a Perseo transformarse en "una sombra viva que [...] es capaz de acercarse y alejarse del 'campo gravitatorio' de las Gorgonas". ${ }^{15}$ Es así como logra alcanzar la morada de las temibles hermanas y acercarse sigilosamente a ellas mientras duermen, llegar hasta Medusa y decapitarla, tomar su cabeza y alejarse de allí. Cuenta el mito que las otras dos Gorgonas le persiguen para vengar la muerte de su hermana, pero no logran darle alcance porque no consiguen verle. Hesíodo,

\footnotetext{
${ }^{12}$ Hesíodo. Teogonía. Trabajos y días. Escudo. Fragmentos. Certamen. Traducción y notas de Aurelio Pérez y Alfonso Martínez. Madrid: Gredos, 1978, p. 185.

${ }^{13}$ Vernant. Op. cit., p. 64.

${ }^{14}$ Francisco Díez de Velasco. Los caminos de la muerte. Religión, rito e imágenes del paso al más allá en la Grecia Antigua. Madrid: Trotta, 1995, p. 37.

${ }^{15}$ Michael Yevzlin. El jardín de los monstruos. Para una interpretación mitosemiótica. Traducción de Milagrosa Romero. Madrid: Biblioteca Nueva, 1999, p. 92.
} 
en Escudo, narra con detalle esa persecución: “Aquel, el Danaida Perseo, estaba en tensión como quien corre y es presa del miedo. Detrás de él, las Gorgonas horrendas e indecibles se precipitaban ansiosas de cogerle".${ }^{16}$ El gorro de Hades, que confiere a Perseo el poder temporal de reinar sobre la muerte y no someterse a ella, le permite eludir la venganza de las Gorgonas y regresar triunfante al mundo de los vivos, donde será largamente recompensado por su éxito: vence a los enemigos que le salen al paso, rescata a su madre Dánae, se casa con la bella princesa Andrómeda, hereda un reino y tiene una numerosa prole.

\section{El ojo como órgano de poder: las Grayas}

La invisibilidad de Perseo, que actúa ocultándose gracias al casco de Hades, tiene su contrapunto en la visión de las Grayas, las tres hermanas que controlan uno de los caminos de entrada a la región de Hades y que cuentan únicamente con un ojo que comparten entre las tres, por turnos, para llevar a cabo esa vigilancia. Resulta paradójico que sea el propio Hades el que haga una excepción a sus normas y ceda a Perseo su gorro, un instrumento mágico que le permitirá eludir el control de las Grayas, sus subordinadas. Hades invita a Perseo a saltarse las reglas y entrar a escondidas en su reino para realizar una tarea, la de decapitar a Medusa, en cuya necesidad todos los dioses y seres humanos concuerdan, pero que casi nadie se atreve a realizar. Luego se verá por qué.

En su Teogonía, Hesíodo escribe que

Ceto tuvo con Forcis a las Grayas de bellas mejillas, canosas desde su nacimiento; las llaman Viejas los dioses inmortales y los hombres que pululan por la tierra. También a [...] las Gorgonas que viven al otro lado del ilustre Océano, en el confín del mundo hacia la noche, donde las Hespérides de aguda voz: Esteno, Euríale y la Medusa desventurada. ${ }^{17}$

Hesíodo no precisa el número de las Grayas ni hace referencia a su único ojo y su único diente, pero esos elementos aparecen en otras versiones del mito. Según Apolodoro, Perseo llega al reino de las Fórcides, llamadas Enío, Pefredo y Dino, que son hijas de Ceto y Forcis, hermanas de las Gorgonas y viejas de nacimiento. ${ }^{18}$ Las tres disponían de un solo ojo y un solo diente, que compartían. Perseo los cogió y cuando se los reclamaron dijo que los devolvería con la condición de que le

\footnotetext{
${ }^{16}$ Hesíodo. Op. cit., p. 185.

${ }^{17}$ Hesíodo. Op. cit., p. 83.

${ }^{18}$ Hay otras tríadas femeninas presentes en la mitología griega, y casi siempre asociadas a la transición entre el mundo de los vivos y de los muertos. Así, por ejemplo, además de las tres Grayas y las tres Gorgonas, puede recordarse a las Moiras o Parcas, las tres hermanas hilanderas encargadas de entretejer los destinos humanos y de cortar los hilos cuando la existencia terrenal llega a su fin.
} 
indicasen el camino que llevaba hasta las Ninfas. Las Fórcides le dieron la información solicitada, y entonces Perseo les devolvió el ojo y el diente. ${ }^{19}$ Ovidio, en sus Metamorfosis, varía un poco la versión y afirma que las Grayas residen en el reino de Atlas y que son dos hermanas, en lugar de tres. En todo caso, "tenían un solo ojo para ambas" ${ }^{20}$ y Perseo aprovecha el momento en que una presta el ojo a la otra para colarse y llegar hasta el palacio de las Gorgonas. En ambas versiones Perseo necesita sustraerse al régimen de visibilidad de las Grayas, ya sea secuestrando su ojo o escondiéndose de él, y ninguna de las dos cosas le supone un gran esfuerzo. En todo caso es fundamental no ser visto, pues si lo descubren intentando entrar en el recinto que ellas custodian sufrirá el castigo de ser triturado por el diente de las Grayas, otro potente órgano de poder. El ojo de las Grayas les sirve para vigilar; el diente, para castigar, ejemplificándose así la conexión directa entre 'surveiller et punir' referida por Foucault.

La facilidad con que Perseo arrebata el ojo de las Grayas pone de manifiesto que ese ojo "no es peligroso en sí, sino al unirse con otro elemento, representado por la cabeza-cuerpo del monstruo". ${ }^{21}$ Las Grayas pueden tomarse como una variante débil de las Gorgonas, ya que viven en el paso hacia el reino de los muertos, es decir, en la periferia, mientras que las Gorgonas habitan en el centro de ese reino. Según la interpretación de Yevzlin, esa posición periférica explica "la incompleta unión del ojo al cuerpo" ${ }^{22}$ en el caso de las Grayas. Las tres usan por turnos un único diente, con el que devoran a quien se atreve a traspasar las fronteras del inframundo sin permiso. Así, el ojo vigila el camino, y ese régimen de visibilidad desplegado desde ese ojo uno y triple activa además el diente que castiga a los curiosos. El ojo es un órgano de poder valiosísimo para las Grayas y están dispuestas a hacer lo que sea, incluso de revelar secretos a un intruso, para recuperar ese ojo y restablecer, por tanto, su posibilidad de mirar, que para ellas se determina principalmente en la función de vigilar y castigar, por decirlo con Foucault.

Perseo no tiene interés alguno en el ojo de las Grayas, ya que él administra y controla un campo de visibilidad mucho más poderoso que el de las tres ancianas: porta el casco de Hades que le permite deambular libremente por el mundo de los muertos, y está a punto de lograr la cabeza de Medusa, un valioso talismán que le permitirá circular por el mundo de los vivos convirtiendo en piedra a quien se interponga en su camino. Con expectativas tan ambiciosas, el ojo de las Grayas le parece a Perseo una bagatela, y se lo devuelve a sus propietarias en cuanto ha obtenido de ellas lo que necesita para seguir adelante con su misión.

\footnotetext{
${ }^{19}$ Apolodoro. Op. cit., p. 93-94.

${ }^{20}$ Ovidio. Las metamorfosis. Traducción de Federico Sainz. 10ª ed. Madrid: Espasa-Calpe, 1989, p. 81.

${ }^{21}$ Yevzlin. Op. cit., p. 88.

${ }^{22}$ Yevzlin. Op. cit., p. 89.
} 


\section{La mirada de la muerte: Medusa}

La derrota de Medusa es la parte central de este mito, y en torno a ese personaje se condensan diversos elementos simbólicos que aluden directamente a la mirada y al poder.

Según consta en las distintas fuentes clásicas, Medusa era la única mortal y la única fecunda de las tres Gorgonas. Ovidio refiere que había sido una joven muy bella y vanidosa, enamorada de sus cabellos. Hesíodo relata los amores de la muchacha con el dios de los mares: "Con ella sola se acostó el de Azulada Cabellera en un suave prado, entre primaverales flores". ${ }^{23}$ De esa unión con el dios engendra Medusa dos figuras extraordinarias, el caballo Pegaso y el gigante Crisaor, que luego serán analizados. También Ovidio recoge este hecho, y cuenta que Poseidón y ella profanaron un templo consagrado a Atenea y que la diosa, ultrajada, castigó a la muchacha: "cada cabello de seda y oro de Medusa se transformó en una inmunda víbora... Víboras que, grabadas en su escudo, utiliza ahora ella para vengarse de sus enemigos". ${ }^{24}$ El castigo de Medusa puede parecer desproporcionado, ya que "sus cabellos se convierten en serpientes, y luego es decapitada", ${ }^{25}$ mientras que Poseidón no recibe ningún tipo de represalia por parte de Atenea, o al menos ninguna de las versiones del mito lo menciona. Pero la diosa de la sabiduría no es la única que desata su ira contra Medusa, sino que todos los olímpicos hallan conveniente que la Gorgona sea destruida y ponen todo su poder al servicio de Perseo para ayudarle en su misión.

Para interpretar este pasaje del mito recurrimos de nuevo a Foucault, que llama la atención sobre el hecho de que "no se puede gobernar sin entrar, de un modo u otro, en el juego de la verdad" ${ }^{26}$ Desde esta otra línea interpretativa, tener poder consiste en dominar la producción de los saberes y discursos que categorizan y clasifican la realidad previamente sometida a regímenes de visibilidad, estableciendo los límites entre el bien y el mal, entre lo aceptable y lo desviado. En la historia de Perseo y Medusa ese poder máximo se lo arrogan las divinidades del Olimpo, que rigen los destinos de las demás criaturas del mundo humano y subterráneo y que estipulan que Medusa es una criatura inapropiada, 'mala' y peligrosa y que consecuentemente debe ser destruida. Perseo es el ejecutor de la voluntad divina, designado para realizar una tarea que los dioses no quieren -o no pueden- llevar a cabo directamente pero para la que le brindan todo su apoyo. Según Yevzlin, los dioses no pueden tener contacto directo con el mundo inferior y por eso recurren a los héroes mitológicos, que cumplen

\footnotetext{
${ }^{23}$ Hesíodo. Op. cit., p. 83.

${ }^{24}$ Ovidio. Op. cit., p. 81.

${ }^{25}$ Pilar Pedraza. La bella, enigma y pesadilla. Esfinge, Medusa, Pantera. Barcelona: Tusquets, 1991, p. 162.

${ }^{26}$ Michel Foucault. Du governement des vivants. Cours au Collège de France, 1979-1980. Paris: Gallimard, 2012, p. 14.
} 
una función intermediaria entre el orden divino y el inframundo. ${ }^{27}$ Sin el concurso de las deidades que le prestan varios objetos mágicos: las sandalias aladas, el gorro, la hoz, la kibisis, etcétera, la hazaña de matar a Medusa no podría haberse realizado.

Medusa es una rival complicada; el poder de su mirada es fortísimo porque "ver la Gorgona es mirarla a los ojos y, con ese cruce de miradas, dejar de ser uno mismo". ${ }^{28}$ Mirarla, incluso después de muerta, paraliza y convierte en piedra instantáneamente a quien lo haga. Puede considerarse esa petrificación que ella induce como una "pérdida del espacio interior", ${ }^{29}$ pues el contacto con sus ojos implica la desaparición del espesor de la subjetividad: todos los elementos de vida interior y de fluidez que caracterizan a la conciencia se vuelven de repente opacos, sólidos, pétreos e inaccesibles. La petrificación es, por lo tanto, una metáfora de la muerte que aniquila toda la subjetividad y que convierte al individuo en materia inerte, despojo de carne, cuerpo inanimado. Como un imán, Medusa atrae las miradas hacia sí. La mirada que se posa en ella queda presa para siempre en ese núcleo de visibilidad, los ojos de Gorgona son como un agujero negro que atrapa toda la materia viva, densificándola y convirtiéndola en piedra inerte. Quien la mira se vuelve inmediatamente igual que ella, es decir, pierde la dimensión subjetiva de la que ella también carece. Emerge aquí la dimensión trágica de la figura de Medusa, privada de subjetividad en varios sentidos.

En primer lugar, Medusa es incapaz de verse a sí misma, ya que entonces sucumbiría a su propio poder petrificante. De hecho, es derrotada cuando Perseo la confronta a su propia imagen, reflejada en el escudo del héroe: no tiene acceso a su propia interioridad porque no se reconoce en el espejo, su imagen monstruosa la aterroriza porque percibe en qué se ha convertido, en qué la ha transformado la diosa Atenea. Ni siquiera la propia Medusa soporta verse a sí misma, siente horror de sí y ese horror se proyecta hacia afuera, de tal modo que toda persona que la mira se contagia al instante del espanto que ella arrastra consigo. Medusa no es sujeto de contemplación sino que es solamente objeto de contemplación en un sentido negativo y radical, porque verla suscita horror y porque quien la contempla se queda paralizado en el acto de mirarla.

Medusa no se reconoce a sí misma de forma directa, y está privada además de la posibilidad de reconocerse a través de la mirada del otro. No tiene acceso a la intersubjetividad porque no puede encontrarse cara a cara con el otro, es incapaz de desplegar una mirada recíproca y alcanzar el auto-reconocimiento y la empatía que llegan a través del "encuentro con la alteridad del Otro, plasmada en el rostro que se sitúa ante mí". ${ }^{30}$ Las miradas que se intercambian, que son bidireccionales y se cen-

\footnotetext{
${ }^{27}$ Yevzlin. Op. cit., p. 104.

${ }^{28}$ Vernant. Op. cit., p. 104.

${ }^{29}$ Yevzlin. Op. cit., p. 89.

${ }^{30}$ Olaya Fernández Guerrero. «Sobre la alteridad y la diferencia sexual». Logos. Anales del seminario de metafisica, 45, 2012, 293-317, p. 297.
} 
tran en el rostro del Otro particularizado que está frente a mí y que a su vez me mira, abren el camino de la empatía y de la tolerancia, llevan a aceptar la diferencia de la otra persona que está frente a mí, que es un ser humano como yo pero que no soy yo, y que percibo como alteridad -como ya indicaron Buber y Levinas-. A Medusa le está vedado ese reconocimiento compartido que surge de la mirada en la que el yo y el tú se captan mutuamente como semejantes y diferentes a un tiempo. Este personaje produce lástima, nadie quiere estar frente a ella porque mirarla a los ojos "es encontrarse frente a frente con el más allá en su dimensión aterradora", ${ }^{31}$ y la propia Medusa es impotente para revertir el efecto que su mirada tiene. Paraliza involuntariamente, es la propia atracción que ejerce la que paraliza a los demás, provoca la muerte al ser mirada, es una muerte pasiva "que surge de las entrañas del oponente" ${ }_{32}$ y que se actualiza por el contacto con la Gorgona. Paradójicamente, la Medusa cuya mirada ejerce un poder omnímodo sobre los seres que la rodean no tiene capacidad de decisión sobre su propia mirada ni elige a quién petrifica, sino que lleva la pesada carga de paralizar indiscriminadamente a todo el que la mira. Ni siquiera su ejecutor, Perseo, llega a mirarla para matarla, ya que se sirve de un escudo para guiarse por el reflejo y ponerse a salvo de sus ojos letales.

Quien tiene una mirada tan poderosa solamente puede ser vencido por los dioses o por quien dispone del favor de estos, de ahí la complejidad de la misión de Perseo. En este punto cabe preguntarse qué representa Medusa y por qué hay que matarla. Desde una interpretación en clave psicoanalítica, se plantea que "las tres Gorgonas simbolizan el enemigo interior que hay que combatir, las deformaciones monstruosas de la psique. El motivo central del mito de Perseo no es otro que el de la dificultad de afrontar la Medusa", ${ }^{33}$ que es en definitiva la dificultad de afrontar los propios miedos, los temores más ancestrales y reprimidos.

El episodio de Perseo decapitando a Medusa presenta paralelismos con el del héroe mitológico Teseo, que se interna en el laberinto de Creta para matar al Minotauro, otro monstruo con una mezcla de rasgos animales y humanos que alude, igual que Medusa, a la monstruosidad que hay en el interior de cada persona y que permanece oculta, al abrigo de todas las miradas. Matar al minotauro supone acabar con la animalidad que afecta a lo humano en su mismo núcleo y poder dar paso a un orden racional, el orden de la polis, representado en ese otro mito por la figura del príncipe ateniense Teseo, que "crea la ley al matar al monstruo". ${ }^{34}$ Nadie quiere entrar en el laberinto del Minotauro por la misma razón que nadie se atreve a mirar a Medusa, porque enfrentarse a los monstruos siempre es peligroso y no hay garantías de vencer

\footnotetext{
${ }^{31}$ Vernant. Op. cit., p. 105.

${ }^{32}$ Pedraza. Op. cit., p. 219.

${ }_{33}$ Josep Antoni Clua. El rostre de la Medusa. Manual de Mitologia Grega en els seus textos literaris. Lleida: Universitat de Lleida, 2010, p. 31.

${ }^{34}$ Jacques Poirier. «Minotaure, mon beau miroir... ». Figures. Cahiers du centre de recherche sur l'image, le symbole, le mythe, 21/23, 1998/1999, 7-19, p. 11.
} 
en la batalla sin el auxilio de los dioses. Y es imprescindible ser de linaje divino, y llamarse Perseo o Teseo, para gozar de ese favor.

Volviendo al personaje de Medusa, la muerte que esta provoca es instantánea e irreversible; quien se convierte en piedra no regresa jamás a la vida.

Las almas que llegan al reino de Perséfone conservan cierta movilidad, que les permite abandonar el reino de los muertos y volver al de los vivos. En el reino de las Gorgonas [...] tiene lugar la inmovilización completa de las almas, es decir, la petrificación, que hace el 'estado de muerte' definitivo o irreversible. ${ }^{35}$

Desde esta lectura la petrificación es como una segunda muerte más profunda y duradera, más sólida e inamovible, porque al transformarlo todo en piedra "las Gorgonas convierten lo muerto en definitivamente muerto, deteniendo así el proceso orgánico" ${ }_{36}$ que permite que, en el nivel subterráneo, la materia viva se descomponga y sirva como germen para el surgimiento de nuevas formas de vida. Gea, la divinidad griega que simboliza la tierra, alude a esa dualidad de vida y muerte, de creación y destrucción, ya que de la tierra emerge todo lo vivo y también al seno de la tierra regresa todo lo que muere, en una constante sucesión de lo uno y su contrario que nos recuerda a Heráclito: "Es siempre uno y lo mismo en nosotros, lo vivo y lo muerto, lo despierto y lo dormido, lo joven y lo anciano. Lo primero se transforma en lo segundo, y lo segundo en lo primero". ${ }^{37}$ Todo fluye y cambia de estado, el paso de la vida a la muerte y de la muerte a la vida es una de las dimensiones centrales de la existencia y está presente a nivel simbólico en todas las religiones de la Antigüedad, incluida la mitología griega, y también en la filosofía presocrática.

Dentro de los procesos de alternancia cíclica de vida y muerte, cielo y tierra, etcétera, la decapitación de Medusa se puede interpretar como una victoria temporal sobre el orden ctónico que ella representa y la instauración de una nueva legalidad basada en la racionalidad y encarnada por los dioses olímpicos, particularmente Zeus y Atenea, directamente relacionados con Perseo. La decapitación "es un acto simbólico que tiene por objeto la liberación de las fuerzas concentradas en la cabeza, que por ello resulta peligrosa". ${ }^{38}$ Decapitar a la Gorgona implica hacerse con el control de un poder que emerge de las profundidades del mundo subterráneo y submarino -recuérdese la conexión de Medusa con Poseidón, dios de los mares y las tempestades- y sacarlo a la luz para utilizarlo en beneficio del orden racional. Es por ello que Perseo no se conforma con cercenar la cabeza de Medusa sino que se la lleva con-

\footnotetext{
${ }^{35}$ Yevzlin. Op. cit., p. 97.

${ }^{36}$ Yevzlin. Op. cit., p. 100.

${ }^{37}$ Parménides, Zenón, Meliso, Heráclito. Fragmentos. Traducción de José Antonio Mínguez. Barcelona: Ediciones Folio, 2002, p. 235.

${ }^{38}$ Yevzlin. Op. cit., p. 87.
} 
sigo, guardada en un zurrón mágico que la protege de las miradas ajenas, para que nadie del mundo de los vivos se encuentre con la muerte-petrificación por accidente, pues Medusa no pertenece al espacio terrestre ni al celeste y su cabeza solo ha de ser visible para aquellas personas concretas a las que Perseo quiere castigar. La cabeza es un elemento de poder en manos del héroe, que además gestiona sus capacidades petrificantes de un modo mucho más 'racional' que la propia Medusa porque ella no puede escoger a quién petrifica, mientras que Perseo sí puede: solo tiene que mostrar la máscara de la Gorgona.

Medusa es un ser intermediario, está en conexión directa con los dioses del inframundo y todo el simbolismo que la rodea alude a ese parentesco. Por ejemplo, sus cabellos son serpientes, animales "ligados a la tierra y las fuerzas telúricas, tanto hostiles como beneficiosas". ${ }^{39}$ Los cabellos simbolizan una manifestación energética y de fertilidad y también tienen que ver con lo terrenal, ${ }^{40} \mathrm{y}$ por tanto con la dualidad de vida y muerte, bien y mal, etcétera. Así, Medusa está revestida de ambivalencia, pues en principio se la asocia a la malignidad pero acaba siendo un elemento protector para Perseo y para la propia Atenea, que porta en su escudo la cabeza de la Gorgona. La mitología griega es abundante en figuras de este tipo -las harpías, las sirenas, los centauros, el Minotauro, o la propia Medusa-, seres híbridos y más o menos monstruosos que combinan rasgos heterogéneos y funcionan como "elementos mediadores entre los términos opuestos", ${ }^{41}$ reconciliándolos.

La progenie de Medusa comparte su función intermediaria entre el mundo terrestre-celeste y el mundo subterráneo. Cuenta Hesíodo que "cuando Perseo le cercenó la cabeza, de dentro brotó el enorme Crisaor y el caballo Pegaso. A este le venía el nombre de que nació junto a los manantiales del Océano, y a aquel porque tenía en sus manos una espada de oro". ${ }^{42}$ Este alumbramiento remite al de la propia Atenea, nacida directamente de la cabeza de su padre, Zeus. En uno de sus episodios amorosos Zeus había dejado embarazada a la titánide Metis. Aconsejado por Gea y Urano, Zeus devora a la diosa gestante. Tiempo después, Zeus siente un fuerte dolor de cabeza. Las deidades del Olimpo intentan remediar en vano el dolor y el dios, incapaz de soportarlo más, pide a su hijo Hefesto que le golpee la cabeza con un hacha. De la brecha surge Atenea, ya adulta, vestida con una armadura brillante y profiriendo un grito de guerra ${ }^{43}$ Atenea es la diosa de la sabiduría, del conocimiento que lo so-

\footnotetext{
${ }^{39}$ Raquel Martín Hernández. «Medusa y las Gorgonas». En: Bernabé, Alberto y Pérez de Tudela, Jorge (eds.). Seres híbridos en la mitología griega. Madrid: Círculo de Bellas Artes, 2012, 153-186, p. 177.

${ }^{40}$ Erika Bornay. La cabellera femenina. Madrid: Cátedra, 1994, p. 39.

${ }^{41}$ Páramo Rocha, Guillermo. «Lógica de los mitos: lógica paraconsistente. Una alternativa en la discusión sobre la lógica del mito». Ideas y valores. Revista colombiana de filosofia, 38, 79, 1989, 27-68, p. 31.

${ }^{42}$ Hesíodo. Op. cit., p. 83.

${ }^{43}$ Aquí se ha seguido la version del mito del nacimiento de Atenea recogida por Harriet Guerber. The Myths of Greece and Rome. Ware: Wordsworth, 2000, p. 45.
} 
brevuela todo. El animal que la simboliza es la lechuza, otra figura del panoptismo; la lechuza emprende su vuelo al atardecer, cuando el día ya ha concluido, y desde esa posición elevada y privilegiada, semioculta en las tinieblas, capta todo lo que ha sucedido. El nacimiento de Atenea es intelectual, la sabiduría surge directamente de la cabeza de Zeus-padre, es decir, de la parte superior de su cuerpo, al igual que Pegaso, el caballo alado que está al servicio de Zeus y de las Musas -que estimulan la creatividad e imaginación-, nace del cuello de su madre decapitada y se eleva por los aires. Pegaso levantó el vuelo nada más nacer y, "abandonando la tierra madre de rebaños, marchó a la mansión de los Inmortales y allí habita, en los palacios de Zeus, llevando el trueno y el rayo al prudente Zeus". ${ }^{44}$ El caballo alado comparte con Medusa ese carácter dual, de mediador entre el mundo celeste y el mundo terrestre, pues en su tarea de transportar el rayo y el trueno "circula constantemente entre el éter donde reside y la zona ctónica a la que pertenece". ${ }^{45}$ Pegaso y Crisaor son hijos de Poseidón, dios de los mares, pero no son la única descendencia de Medusa. Según Hesíodo, la Gorgona tuvo en una gruta otro monstruo extraordinario: "la divina y astuta Equidna, mitad ninfa de ojos vivos y hermosas mejillas, mitad en cambio monstruosa y terrible serpiente, enorme, jaspeada, sanguinaria, bajo las entrañas de la venerable tierra. Allí habita una caverna en las profundidades". ${ }^{46}$ Equidna es otra síntesis de lo bello y lo terrible: en ella se alternan elementos hermosos, como los ojos y mejillas, y rasgos monstruosos, pues su cuerpo es serpentino al igual que los cabellos de su progenitora. La fecundidad de Medusa no concluye aquí, pues cuenta Ovidio que de las gotas de sangre derramadas por su cabeza mientras Perseo la transporta en la kibisis surge una estirpe de serpientes e insectos venenosos que desde entonces pueblan las arenas del desierto de Libia. ${ }^{47}$ En definitiva, la fertilidad de este personaje mitológico es prodigiosa y su prole es heterogénea, en tanto que comparte con ella ese carácter intermediario entre lo terrestre y lo celeste: la Gorgona engendra en solitario a un monstruo híbrido, mitad serpiente y mitad doncella, y además de su tronco surgen en sentido ascendente un gigante con espada y un caballo volador, y de su cabeza en pleno vuelo nacen en sentido descendente innúmeros reptiles. De la madre Medusa -que desde esta perspectiva puede interpretarse como un alter ego de Gea, la madre tierra- nacen seres aéreos, terrestres y subterráneos, alados y reptantes, gigantes y diminutos, capaces de inspirar lo más sublime -la imaginación representada por Pegaso- o lo más terrible -el espanto que genera Equidna-.

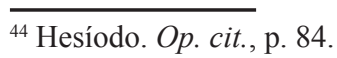

${ }^{45}$ Vernant. Op. cit., p. 91.

${ }^{46}$ Hesíodo. Op. cit., p. 84.

${ }^{47}$ Ovidio. Op. cit., p. 78.
} 


\section{El avistamiento del premio: Andrómeda}

Una vez concluida su tarea de decapitar a Medusa, Perseo emprende el viaje de regreso a Sérifos. Para realizar el trayecto más rápido se sirve de las sandalias aladas de Hermes, que le permiten sobrevolar el mundo y observarlo todo desde las alturas. Refiere Ovidio que Perseo llega a Etiopía "en el mismo momento en que Andrómeda, para expiar un crimen de su madre, había de perecer por una injusta sentencia" ${ }^{48}$ Él se siente fascinado al momento por la belleza de Andrómeda, en lo que podría describirse como 'amor a primera vista': "Perseo, viendo a esta joven princesa atada a una roca y expuesta a la voracidad de un monstruo marino... quedó enamorado de su belleza y de la bondad que brillaba en sus ojos". ${ }^{49}$ Perseo observa con atención lo que su destino de héroe le depara: una princesa bella y buena; su bondad es tan evidente que se refleja en su mirada. En este sentido Andrómeda es el contrapunto de Medusa, a la que Perseo no se habría atrevido a mirar a los ojos bajo ningún concepto, pues la mirada de la Gorgona arrastra a la petrificación, a la parálisis y a la cancelación del movimiento. La mirada de Andrómeda desencadena el efecto contrario, tiene el poder de despertar el sentimiento amoroso e incita a Perseo a actuar con rapidez, acercarse a la princesa y preguntarle la causa de su castigo. Ella acaba confesando que su situación se debe "a las excesivas vanidades de su madre, comparándose en hermosura con Juno y las Nereidas". ${ }^{50} \mathrm{El}$ héroe no se detiene ante nada, y se ofrece a salvarla del dragón con la condición de que luego ella sea su esposa.

La historia tiene final feliz: Perseo vence al dragón y se casa con Andrómeda. Ese monstruo marino al que Perseo ha de derrotar para rescatar a su princesa parece una reduplicación de Medusa, como señala Pilar Pedraza. ${ }^{51}$ Sin embargo, según el relato de Ovidio, Perseo no usa la cabeza de Medusa para vencer al dragón, sino que se sirve de su espada... ¿será que el monstruo marino que pretende engullir a Andrómeda es demasiado próximo a la propia Medusa, y por tanto inmune a sus efectos? Perseo se acerca al monstruo y lo ataca de este modo: "Se alzó en el espacio y, como un rayo, se dejó caer sobre el lomo de la bestia con la espada desnuda; penetró ésta hasta el puño en el ojo del monstruo. [...] Nuevo ataque de éste; y la espada se clava en el vientre de la bestia". ${ }^{52}$ Así, el héroe se equipara a los dioses, vence desde el aire -porque lleva las sandalias aladas de Hermes- y cae sobre el monstruo con la misma velocidad del rayo de Zeus. Y lo primero que hace es inutilizar el ojo del dragón marino... hallamos aquí otra referencia a la visibilidad. Para vencer al monstruo, Perseo intenta primero privarlo de la capacidad de ver y con ello quitarle su poder,

\footnotetext{
${ }^{48}$ Ovidio. Op. cit., p. 79.

${ }^{49}$ Ovidio. Op. cit., p. 79.

${ }^{50}$ Ovidio. Op. cit., p. 80.

${ }^{51}$ Pedraza. Op. cit., p. 171.

${ }^{52}$ Ovidio. Op. cit., p. 80.
} 
ataca su ojo al igual que había hecho antes con las Grayas y con Medusa, a la que priva del poder de su mirada. 'Ciega y vencerás', podría ser la máxima que resume las actuaciones de este héroe.

Perseo es el gran gestor de las miradas ajenas, estipula lo que puede y no puede ser visto porque manipula a su antojo los regímenes de visibilidad e invisibilidad de los seres humanos y de las criaturas subterráneas y submarinas a las que pretende dominar. Cegando al monstruo marino evita que Andrómeda siga estando en el campo visual de la bestia. Y atacando su vientre impide que el dragón pueda devorarla. Pero lo primordial es controlar la mirada para que el monstruo no vea a Andrómeda, del mismo modo que, 'secuestrando' el ojo de las Grayas, Perseo logra ponerse a salvo de que lo vean y puedan devorarlo con su diente...

Controlar la mirada ajena es una de las modalidades de poder que ejerce Perseo y que se repite en otros episodios de la mitología griega, como por ejemplo en la derrota del gigante Argos por parte del dios Hermes. Zeus había sido infiel a su esposa Hera con la ninfa Ío. Para que su esposa no sospechase, Zeus transforma a la muchacha en una vaca. Pero Hera está recelosa y encarga a Argos, gigante de cien ojos, que custodie a la hermosa res e impida que ningún ser, ni humano ni divino, se acerque a ella. Pero, cuenta Ovidio, el dios añora a Ío "y llama a Mercurio ordenándole que mate al feroz guardián. Para obedecer a este mandato, Mercurio quita las alas a sus pies, toma el sombrero y la varita de adormidera". ${ }^{53}$ El dios se sirve de engaños para lograr que el gigante se adormezca y cuando este cierra sus cien ojos, lo degüella. Lo mismo que Perseo hace con Medusa.

\section{El escudo/espejo: el poder sobre sí}

Perseo no conserva eternamente la cabeza de Medusa - ¿es acaso demasiado poder en manos de un mortal?- ni tampoco los objetos que los dioses le prestan para acometer su hazaña. Devuelve las sandalias aladas, el casco de invisibilidad y la kibisis, que regresan a las manos de sus legítimos propietarios, los dioses. El héroe vuelve a la normalidad, se casa con Andrómeda y cumple con su destino prescrito por un oráculo: mata a su abuelo, el rey Acrisio, lo que le permite heredar un reino en el que vivirá tranquilamente el resto de sus días y en el que tendrá una larga prole junto a su princesa. ${ }^{54}$ Esa entrega restablece el equilibrio de poder entre dioses y hombres, pues los mitos muestran que ningún mortal está capacitado para exponerse durante mucho tiempo a los elementos de origen divino -puede recordarse a este respecto la historia del desdichado Faetón, que pidió al dios Helios que le dejase guiar el carro solar como prueba de su paternidad y murió fulminado en el intento, o a la ninfa Semele, que falleció abrasada por los rayos de Zeus cuando pidió a este que se

\footnotetext{
${ }_{53}$ Ovidio. Op. cit., p. 51.

${ }^{54}$ Esta es la versión que recoge Apolodoro. Op. cit., p. 97.
} 
mostrase ante ella con su forma divina y no con el aspecto humano que el dios había adoptado para intentar seducirla-.

En la restitución de los bienes divinos que lleva a cabo Perseo, resulta llamativo que la cabeza de la Medusa sea entregada a Atenea y no a Hades, rey del inframundo de donde la Gorgona procede, o a Poseidón, progenitor de una parte de su descendencia.

Además, Atenea acepta el don y lo lleva siempre consigo a partir de ese momento, situado en un lugar bien visible: la diosa no transporta la cabeza escondida en la kibisis como había hecho Perseo, sino que la coloca en el centro de su escudo para que todos puedan contemplarla. Para matar a Medusa, Perseo recurre a su escudo que le devuelve el reflejo de la Gorgona y le sirve de guía para llegar hasta ella y decapitarla. Y ahora el escudo de Atenea, con la cabeza de Medusa colocada en el centro, acaba siendo una réplica de ese escudo de Perseo, solo que en el caso de la diosa no es el reflejo de la Medusa, sino la Medusa misma, lo que el escudo contiene. De este modo se visibiliza su triunfo: la cabeza es el trofeo que atestigua la victoria de Atenea sobre Medusa. "Medusa puede ser la Otra, el gran Doble de las culpas inconfesables, el Doble que solo se reconoce en el espejo. Matarla y exhibir su cabeza ensangrentada es lo propio de la diosa de la Razón", ${ }^{55}$ que de ese modo presume de haber vencido sobre sus contradicciones, deseos y miedos. Pero esa victoria no es definitiva sino que necesita un recordatorio constante: lo negativo siempre acecha y Atenea no puede bajar la guardia, porque entonces lo monstruoso se apoderaría de todo. El sueño de la razón produce monstruos y el orden de Zeus -de lo racionalnecesita que su hija, que brota directamente de su cabeza a plena luz del día y a la vista de todos, destine todas sus energías a reprimir y poner veto a lo monstruoso, aunque nunca logrará erradicarlo por completo. En un sentido negativo, la cabeza de Medusa colocada en el escudo de Atenea remite a esa presencia permanente de lo telúrico, de lo oculto y lo inconsciente que subyace a todas y cada una de las producciones de nuestro intelecto, y a la necesidad de ponerle cerco para poder desplegar el conocimiento.

Atenea es la deidad de la sabiduría, es la "Razón, la enemiga de los monstruos, es también su dueña y señora, la que los somete y protege, quien les da muerte y se apropia de sus despojos" ${ }^{56}$ Colocando a la Gorgona en su escudo, Atenea se reviste del poder que le transfiere ese elemento. En manos de la diosa, el escudo-espejo funciona como elemento protector y peligroso a la vez. En su nueva ubicación, la mirada de la Gorgona es un espejo en el que el individuo se ve reflejado y se queda aterrorizado por la monstruosidad que forma parte de él mismo: "Medusa es un espejo deformante, en el que me miro y me veo más hermosa, pero también más horrible de lo que soy en realidad. Con ella no vale más arma que otro espejo, el espejo atenaico

\footnotetext{
${ }^{55}$ Pedraza. Op. cit., p. 179.

${ }^{56}$ Pedraza. Op. cit., p. 176.
} 
de la verdad". ${ }^{57}$ Atenea obliga a quien pretenda adentrarse por el camino de la sabiduría a mirar de frente a Medusa, esto es, a ver reflejados en el escudo-espejo los miedos e inseguridades, la fealdad que subyacen en lo más profundo del inconsciente y cuya visión a la luz del día produce pavor. La máscara de la Gorgona que aparece en el escudo o que decoraba el fondo de las copas utilizadas para beber vino en los simposios "es la aniquilación que acecha, pero también el símbolo del conocimiento del noble griego que ha deambulado en vida por los abruptos caminos de la muerte". ${ }^{58}$ Desde aquí cabe hacer una lectura positiva de la presencia de Medusa en el escudo atenaico, pues aprender a mirarla de frente implica aceptar abiertamente la propia finitud, la fealdad y las contradicciones que nos constituyen, es decir, todo aquello que prolifera al margen de la norma, fuera de los límites de 'racionalidad' que son construidos artificialmente y que acaban 'legislando' sobre los cuerpos y las vidas y ejerciendo biopoder, dirá Foucault. Quien consigue tolerar su propia a-normalidad se inmuniza contra los efectos paralizantes de Medusa, sale fortalecido y endurecido de esa experiencia -fuerte como una piedra- pero no por ello se inmoviliza sino que, al contrario, se reviste de una solidez que le permite avanzar con más confianza en ese proceso del 'conócete a ti mismo' que ya recomendaba el antiguo oráculo de Delfos.

"Solo un arma, el espejo de la verdad, puede proteger al hombre del peligro de Medusa". ${ }^{59}$ El escudo-espejo acaba siendo un elemento protector porque nos obliga a afrontar todo lo que somos, y así nos pone a salvo del poder paralizante que nuestros miedos e inseguridades pueden ejercer sobre nosotros. La diosa de la sabiduría que porta ese escudo-espejo nos recuerda que ella ya ha llevado a cabo ese 'conocimiento de sí', e invita a adentrarse por esa senda a todo el que se sitúa ante ella. En este sentido "el arma de Atenea [...] me devuelve mi imagen verdadera", ${ }^{60}$ muestra el aspecto actual, el que corresponde al mundo de los vivos, pero también incluye su cara negativa, Medusa, donde se reflejan los peligros que acechan constantemente: la muerte y la destrucción que llevamos dentro y que acabarán por adueñarse de todo. La muerte está en el centro de la vida porque toda vida contiene el germen de su propia destrucción -somos 'seres-para-la-muerte', escribió Heidegger-, y esto es lo que realmente aterroriza de Medusa: su amenaza es real, porque todos sin excepción acabaremos portando la máscara de la muerte. Lo que muestra la máscara-espejo de Gorgona es "tú mismo en el más allá, esta cabeza vestida de noche, esta cara enmascarada de invisibilidad que, en el ojo de Gorgo, demuestra ser la verdad de tu propia cara". ${ }^{61}$ El escudo-espejo de Atenea nos refleja tal cual somos mientras vivimos, pero contiene también la máscara de Gorgona que nos muestra cómo seremos, que

\footnotetext{
${ }^{57}$ Pedraza. Op. cit., p. 222.

${ }^{58}$ Díez de Velasco. Op. cit., p. 112.

${ }^{59}$ Clua. Op. cit., p. 81.

${ }^{60}$ Pedraza. Op. cit., p. 223.

${ }^{61}$ Vernant. Op. cit., p. 106.
} 
nos recuerda nuestra condición de futuros cadáveres. Atenea y Medusa son complementarias, remiten la una a la otra y juntas proporcionan una visión integrada de lo humano, caracterizado por las dualidades entre vida y muerte, intelecto y materia, alma y cuerpo, cielo y tierra, poder y resistencia, simbolizadas respectivamente por cada una de ellas.

Se cierra aquí el círculo de la mirada y el poder; el escudo de Atenea/Medusa devela que el máximo nivel de poder que se puede ejercer a través de la mirada surge cuando el individuo vuelve la mirada hacia sí mismo, intentando desentrañar todas las caras ocultas de su propia existencia. Esa auto-observación es una práctica de poder que ya no busca controlar a los demás sino que se despliega internamente para desvelar aspectos inadvertidos o silenciados, y para confrontarse con todos los elementos a los que desagrada mirar de frente. El panoptismo foucaultiano aparece de nuevo, aquí aplicado a la propia interioridad: a partir del momento en que el individuo alcanza la capacidad de verlo todo y aceptarlo todo acerca de sí mismo, logra sustraerse del poder que se ejerce sobre él heterónomamente. Quien percibe todas las relaciones de poder en que está inmerso y que transitan su psique y modulan su acción, quien no teme al caos que lleva dentro de sí y se asoma valientemente al 'abismo de su propio ser' -como recomienda Nietzsche inspirándose en el pensamiento griego-, es más dueño de sí mismo y queda inmunizado contra la Medusa.

Ella nos observa desde el fondo del vaso, pero si apuramos el líquido de la copa habremos ingerido el antídoto contra el poder que su mirada ejerce. 


\section{Bibliografía}

Apolodoro. Biblioteca. Traducción de Margarita Rodríguez. Madrid: Gredos, 1985.

Aragüés, Juan Manuel. De la vanguardia al cyborg. Aproximaciones al paradigma posmoderno. Zaragoza: Eclipsados, 2012.

Bornay, Erika. La cabellera femenina. Madrid: Cátedra, 1994.

Clua, Josep Antoni. El rostre de la Medusa. Manual de Mitologia Grega en els seus textos literaris. Lleida: Universitat de Lleida, 2010.

Deleuze, Gilles. Foucault. 2a ed. Paris: Éditions de Minuit, 2004.

Detienne, Marcel. La invención de la mitología. Traducción de Marco Aurelio Galmarini. Barcelona: Península, 1985.

Díez de Velasco, Francisco. Los caminos de la muerte. Religión, rito e imágenes del paso al más allá en la Grecia Antigua. Madrid: Trotta, 1995.

Fernández Guerrero, Olaya. «Sobre la alteridad y la diferencia sexual». Logos. Anales del Seminario de Metafísica, 45, 2012, 293-317.

Foucault, Michel. Surveiller et punir. Naissance de la prison. Paris: Gallimard, 1975 La pensée du dehors. $2^{\mathrm{a}}$ ed. Paris: Fata Morgana, 2009.

Du governement des vivants. Cours au Collège de France, 1979-1980. Paris: Gallimard, 2012.

García Gual, Carlos. Diccionario de mitos. Barcelona: Planeta, 1997.

Guerber, Harriet. The Myths of Greece and Rome. Ware: Wordsworth, 2000.

Hesíodo. Teogonía. Trabajos y días. Escudo. Fragmentos. Certamen. Traducción y notas de Aurelio Pérez y Alfonso Martínez. Madrid: Gredos, 1978.

Martín Hernández, Raquel. «Medusa y las Gorgonas». En: Bernabé, Alberto y Pérez de Tudela, Jorge (eds.). Seres híbridos en la mitología griega. Madrid: Círculo de Bellas Artes, 2012, 153-186.

Ovidio. Las metamorfosis. Traducción de Federico Sainz. 10ª edición. Madrid: Espasa-Calpe, 1989.

Páramo Rocha, Guillermo. «Lógica de los mitos: lógica paraconsistente. Una alternativa en la discusión sobre la lógica del mito». Ideas y valores. Revista colombiana de filosofia, 38, 79, 1989, 27-68.

Parménides, Zenón, Meliso, Heráclito. Fragmentos. Traducción de José Antonio Míguez. Barcelona: Ediciones Folio, 2002 
Pedraza, Pilar. La bella, enigma y pesadilla. Esfinge, Medusa, Pantera. Barcelona: Tusquets, 1991.

Poirier, Jacques. « Minotaure, mon beau miroir... ». Figures. Cahiers du centre de recherche sur l'image, le symbole, le mythe, 21/23, 1998-1999, 7-19.

Sartori, Giovanni. Homo videns: La sociedad teledirigida. Madrid: Santillana-Taurus, 1998.

Vernant, Jean-Pierre. La muerte en los ojos. Figuras del Otro en la antigua Grecia. Traducción de Daniel Zadunaisky. Barcelona: Gedisa, 1986.

Yevzlin, Michael. El jardín de los monstruos. Para una interpretación mitosemiótica. Traducción de Milagrosa Romero. Madrid: Biblioteca Nueva, 1999.

Olaya Fernández Guerrero

UNED Centro asociado de La Rioja

olayafg@yahoo.es 